\title{
Intermetallic Compounds Formed in Sn-20In-2.8Ag Solder BGA Packages with Ag/Cu Pads
}

\author{
C.C. Jain, S.S. Wang, K.W. Huang, and T.H. Chuang
}

(Submitted January 24, 2008; in revised form July 11, 2008)

\begin{abstract}
The interfacial reactions in a Sn-20In-2.8Ag solder ball grid array (BGA) package with immersion Ag surface finish are investigated. After reflow, the Ag thin film dissolves quickly into the solder matrix, and scallop-shaped intermetallic layers, with compositions of $\left(\mathrm{Cu}_{0.98} \mathrm{Ag}_{0.02}\right)_{6}\left(\mathrm{In}_{0.59} \mathrm{Sn}_{0.41}\right)_{5}$, appear at the interfaces between $\mathrm{Sn-20In-2.8Ag}$ solder ball and $\mathrm{Cu}$ pad. No evident growth of the $\left(\mathrm{Cu}_{0.98} \mathrm{Ag}_{0.02}\right)_{6}$ $\left(\mathrm{Sn}_{0.59} \mathrm{In}_{0.41}\right)_{5}$ intermetallic compounds was observed after prolonged aging at $100{ }^{\circ} \mathrm{C}$. However, the growth accelerated at $150{ }^{\circ} \mathrm{C}$, with more intermetallic scallops floating into the solder matrix. The intermetallic thickness versus the square root of reaction time $\left(t^{1 / 2}\right)$ shows a linear relation, indicating that the growth of intermetallic compounds is diffusion-controlled. Ball shear tests show that the strength of $\mathrm{Sn}-20 \mathrm{In}-2.8 \mathrm{Ag}$ solder joints after reflow is $4.4 \mathrm{~N}$, which increases to $5.18 \mathrm{~N}$ and $5.14 \mathrm{~N}$ after aging at 100 and $150{ }^{\circ} \mathrm{C}$, respectively.
\end{abstract}

Keywords BGA package, immersion Ag surface finish, interfacial reactions, Sn-20In-2.8Ag

\section{Introduction}

In order to prevent oxidation and promote the wettability of a printed circuit board, many surface finishing techniques have been explored, among which the immersion $\mathrm{Au} / \mathrm{Ni}$ method is popularly employed in advanced electronic packaging (Ref 1). However, this method is costly and in some cases can cause $\mathrm{Au}$ embrittlement failure (Ref 2). Immersion Ag is an alternative surface finishing agent, which can provide smooth surfaces and good wettability for liquid solders on $\mathrm{Cu}$ pads (Ref 3). In addition, the process involving immersion $\mathrm{Ag}$ takes about $7 \mathrm{~min}$, and the cost is close to those with traditional Sn surface finishes. An immersion $\mathrm{Ag}$ film is about $0.2 \mu \mathrm{m}$ thick and dissolves quickly into the solder matrix during reflow, allowing further interfacial reaction to occur between the solder alloy and the $\mathrm{Cu}$ pad.

Sn-3.5Ag solder possesses the merits of high strength, improved creep resistance, longer fatigue life, and good wettability (Ref 4). However, the high melting temperature $\left(221^{\circ} \mathrm{C}\right)$ of this eutectic alloy hastens the dissolution of the $\mathrm{Cu}$ pad into the liquid solder and results in the rapid growth of intermetallic compounds. Also, commonly used FR-4 printed circuit boards can be damaged during very high temperature reflow. Sn-20In-2.8Ag solder has been developed to solve this problem by adding the element indium to lower the melting points and increase the wettability (Ref 5). Shimizn et al. further indicated that indium-based solders possess a more durable

C.C. Jain, S.S. Wang, K.W. Huang, and T.H. Chuang, Department of Materials Science and Engineering, National Taiwan University, Taipei 106, Taiwan. Contact e-mail: tunghan@ntu.edu.tw.

fatigue life than $\mathrm{Pb}-\mathrm{Sn}$ solders and are well suited for high reliability interconnections ( Ref 6). The interfacial reactions of $\mathrm{Sn}-20 \mathrm{In}-2.8 \mathrm{Ag}$ solders with $\mathrm{Ni}$ and $\mathrm{Ag}$ substrates have been investigated, which led to the formation of $\mathrm{Ni}_{3}\left(\mathrm{Sn}_{0.99} \mathrm{In}_{0.01}\right)_{4}$ and $\mathrm{Ag}_{2}(\mathrm{In}, \mathrm{Sn})$ intermetallic compounds, respectively (Ref 7, 8). The intermetallic reactions in $\mathrm{Sn}-20 \mathrm{In}-2.8 \mathrm{Ag}$ solder ball grid array (BGA) packages with $\mathrm{Au} / \mathrm{Ni} / \mathrm{Cu}$ pads have also been previously investigated (Ref 9), revealing the formation of $\mathrm{Ni}\left(\mathrm{Sn}_{0.72} \mathrm{In}_{0.28}\right)_{2}$ phase at the solder/pad interfaces after the reflowing process and aging at $100{ }^{\circ} \mathrm{C}$. However, after aging at a higher temperature of $150{ }^{\circ} \mathrm{C}$, many column-shaped $\left(\mathrm{Cu}_{0.74} \mathrm{Ni}_{0.26}\right)_{6}\left(\mathrm{Sn}_{0.92} \mathrm{In}_{0.08}\right)_{5}$ intermetallics grew rapidly from the solder/pad interface into the solder matrix (Ref 9). Although immersion Ag has become popular for surface finishing of $\mathrm{Cu}$ pads in electronic packaging, the intermetallic compounds formed in such solder joints are scantily researched. The effort of this study is concerned with the interfacial reactions of Sn-20In-2.8Ag solder balls with $\mathrm{Ag} / \mathrm{Cu}$ pads in reflowed and aged BGA packages, as well as the effect of immersion Ag on the shear strength of the solder joints.

\section{Experimental}

The BGA package used in this study contained $49 \mathrm{Cu}$ pads set on each FR-4 substrate. The $\mathrm{Cu}$ pads were immersion-plated with $0.2 \mu \mathrm{m}$ thick Ag film. The Sn-20In-2.8Ag solder balls, with diameters of $0.4 \mathrm{~mm}$, were dipped in RMA type flux, placed on the immersion $\mathrm{Ag} / \mathrm{Cu}$ pads of the BGA packages, and then heated in a hot-air furnace. The solidus and liquidus of Sn-20In-2.8Ag as analyzed by DSC (see Fig. 1) are 176.3 and $187.7^{\circ} \mathrm{C}$, respectively. The reflow temperature profile with a peak temperature at $230{ }^{\circ} \mathrm{C}$ for a melting time of $60 \mathrm{~s}$ $\left(T>176.3{ }^{\circ} \mathrm{C}\right)$ is shown in Fig. 2. After reflow, the specimens were further aged at 100 and $150{ }^{\circ} \mathrm{C}$ for durations varying from 100 to $1000 \mathrm{~h}$. To investigate the metallographic microstructure, the solder joints were mounted with resin and then ground 


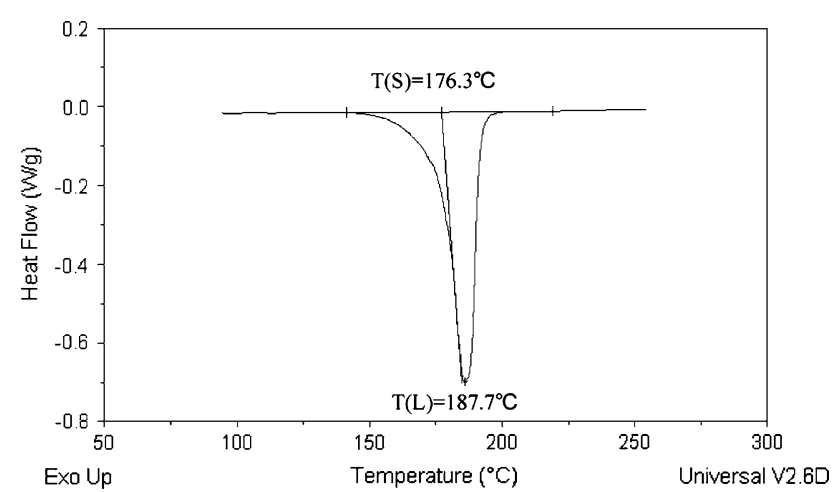

Fig. 1 Solidus and liquidus of Sn-20In-2.8Ag solder as shown in the DSC curve

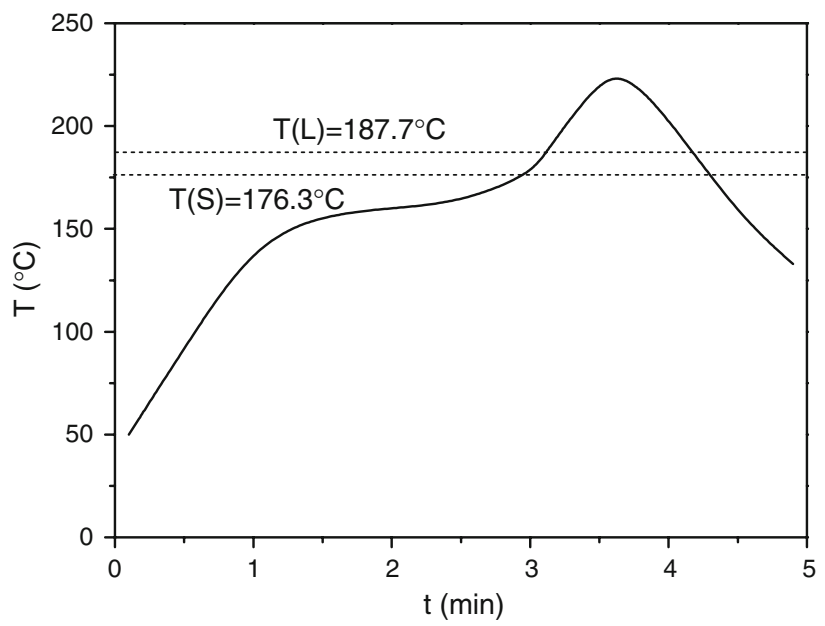

Fig. 2 Temperature profile for the reflowed Sn-20In-2.8Ag BGA packages within this study

with 1500 grit $\mathrm{SiC}$ paper and polished with $0.3 \mu \mathrm{m} \mathrm{Al}_{2} \mathrm{O}_{3}$ powder in order to obtain the crosssections of the solder/pads interfaces. The morphology of the intermetallic compounds was examined via scanning electron microscopy (SEM). Energy dispersive X-ray (EDX) spectrometry was used to determine the chemical composition of the intermetallic compounds.

In addition, the bonding strengths of the Sn-20In-2.8Ag solder joints after reflow and aging were measured via ball shear testing. The measurements were taken at a shear rate of $0.1 \mathrm{~mm} / \mathrm{s}$ and a shear height of $80 \mu \mathrm{m}$ (about $1 / 4$ of the reflowed ball height). Fractography of the solder joints after ball shear testing was conducted by SEM.

\section{Results and Discussion}

The typical microstructure of the as-cast Sn-20In-2.8Ag alloy is shown in Fig. 3, where a great number of island-like $\mathrm{Ag}_{2} \mathrm{In}$ precipitates are embedded in the Sn-rich matrix. After reflow, the Ag thin film dissolves quickly, and scallop-shaped intermetallic compounds appear at the interface between Sn-20In-2.8Ag solder balls and the immersion $\mathrm{Ag} / \mathrm{Cu}$ pad, as shown in Fig. 4. The chemical composition (at.\%) of the

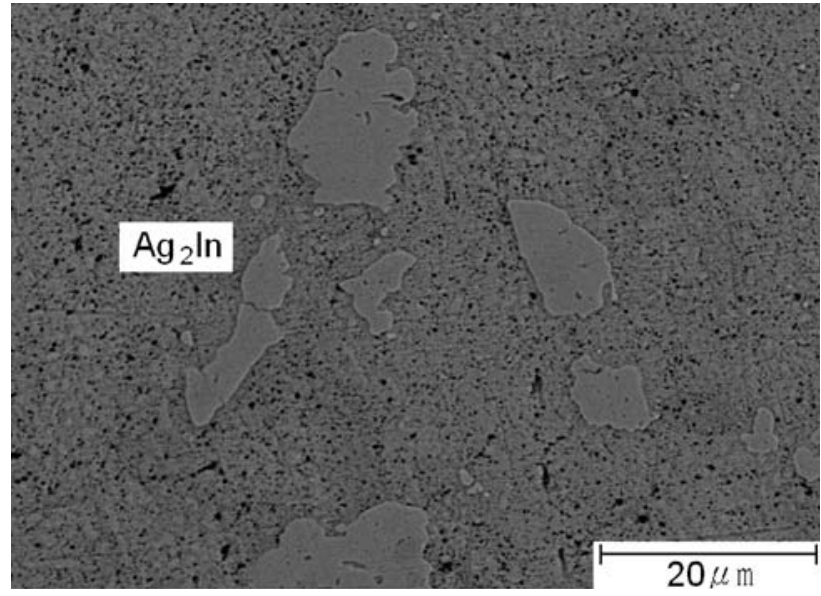

Fig. 3 Microstructure of the as-cast Sn-20In-2.8Ag solder matrix on Ag immersion surface finished pads

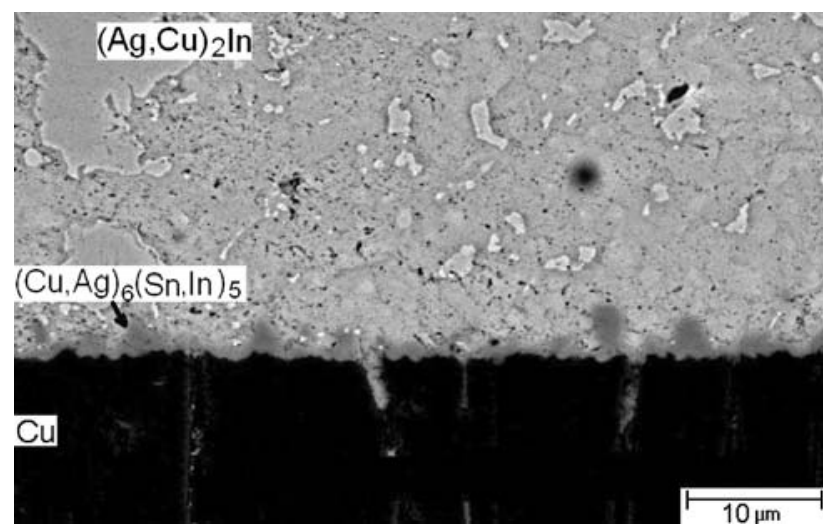

Fig. 4 Morphology of the intermetallic compounds formed at the immersion $\mathrm{Ag}$ surface finished interface of reflowed Sn-20In-2.8Ag solder BGA packages

intermetallic layer as analyzed by EDX is Cu:Ag: $\mathrm{Sn}: \mathrm{In}=55.46$ : 1.08:28.52:14.94, which corresponds to the $\eta-\left(\mathrm{Cu}_{0.98} \mathrm{Ag}_{0.02}\right)_{6}$ $\left(\mathrm{Sn}_{0.59} \mathrm{In}_{0.41}\right)_{5}$ phase. The formation of such $\eta-\left(\mathrm{Cu}_{0.98} \mathrm{Ag}_{0.02}\right)_{6}$ $\left(\mathrm{Sn}_{0.59} \mathrm{In}_{0.41}\right)_{5}$ intermetallics is due to the dissolution of $\mathrm{Ag}$ thin film and the interfacial reactions between Sn-20In-2.8Ag solder and $\mathrm{Cu}$ pad. However, the $\mathrm{Cu}$ pad also dissolves into the solder matrix to cause the change of the composition of island-like $\mathrm{Ag}_{2}$ In precipitates to $\mathrm{Ag}: \mathrm{Cu}: \mathrm{In}=63.66: 3.85: 32.49$, which corresponds to the $\left(\mathrm{Ag}_{0.94} \mathrm{In}_{0.06}\right)_{2} \mathrm{In}$ phase.

In the prior study, coarse $\mathrm{Ag}_{3} \mathrm{Sn}$ plates were observed during the soldering reaction of liquid $\mathrm{Sn}$ and $\mathrm{Sn}-3.5 \mathrm{Ag}$ with the $\mathrm{Ag}$ substrates (Ref 10). Also, some large $\mathrm{Ag}_{3} \mathrm{Sn}$ plates appeared in solder matrix have reported in the $\mathrm{Sn}-\mathrm{Ag}-\mathrm{Cu}$ solder joints (Ref 11, 12). Lee et al. investigated the appearance of such large intermetallic compounds in the solder and pointed out a harmful effect on the mechanical properties of the solder joints (Ref 13). Figure 4 reveals that no $\mathrm{Ag}_{3} \mathrm{Sn}$ precipitates appear in the Sn-20In-2.8Ag solder matrix. This result is consistent with the observation of Chiang ( $\operatorname{Ref} 8$ ) that the addition of In into the $\mathrm{Sn}$-rich solder can suppress the formation of $\mathrm{Ag}_{3} \mathrm{Sn}$ intermetallic compounds.

Figure 5 shows the morphology of intermetallic compounds in $\mathrm{Sn}-20 \mathrm{In}-2.8 \mathrm{Ag}$ solder BGA packages with immersion $\mathrm{Ag}$ pads after aging at $100{ }^{\circ} \mathrm{C}$ for various times. It can be seen that 
the interfacial intermetallic compounds $\eta-\left(\mathrm{Cu}_{0.98} \mathrm{Ag}_{0.02}\right)_{6}$ $\left(\mathrm{Sn}_{0.59} \mathrm{In}_{0.41}\right)_{5}$ formed during the reflow process have not grown obviously with the aging time, yet a small number of $\eta-\left(\mathrm{Cu}_{0.98} \mathrm{Ag}_{0.02}\right)_{6}\left(\mathrm{Sn}_{0.59} \mathrm{In}_{0.41}\right)_{5}$ intermetallic clusters float into the solder matrix after aging. The composition of the interfacial intermetallic compounds shows no change with the increase of aging time, while more intermetallic scallops float away from the solder pad. In addition, there is a slight coarsening of $\left(\mathrm{Ag}_{0.94} \mathrm{Cu}_{0.06}\right)_{2} \mathrm{In}$ in the solder matrix. Figure 6 shows the accelerated growth of the $\eta-\left(\mathrm{Cu}_{0.98} \mathrm{Ag}_{0.02}\right)_{6}\left(\mathrm{Sn}_{0.59} \mathrm{In}_{0.41}\right)_{5}$ intermetallic compounds with the aging time when the aging temperature is increased to $150{ }^{\circ} \mathrm{C}$. It can also be observed that only the $\eta-\left(\mathrm{Cu}_{0.98} \mathrm{Ag}_{0.02}\right)_{6}\left(\mathrm{Sn}_{0.59} \mathrm{In}_{0.41}\right)_{5}$ intermetallic layer appears at the interface. For the $\mathrm{Cu} / \mathrm{Sn}$ interfacial reactions,
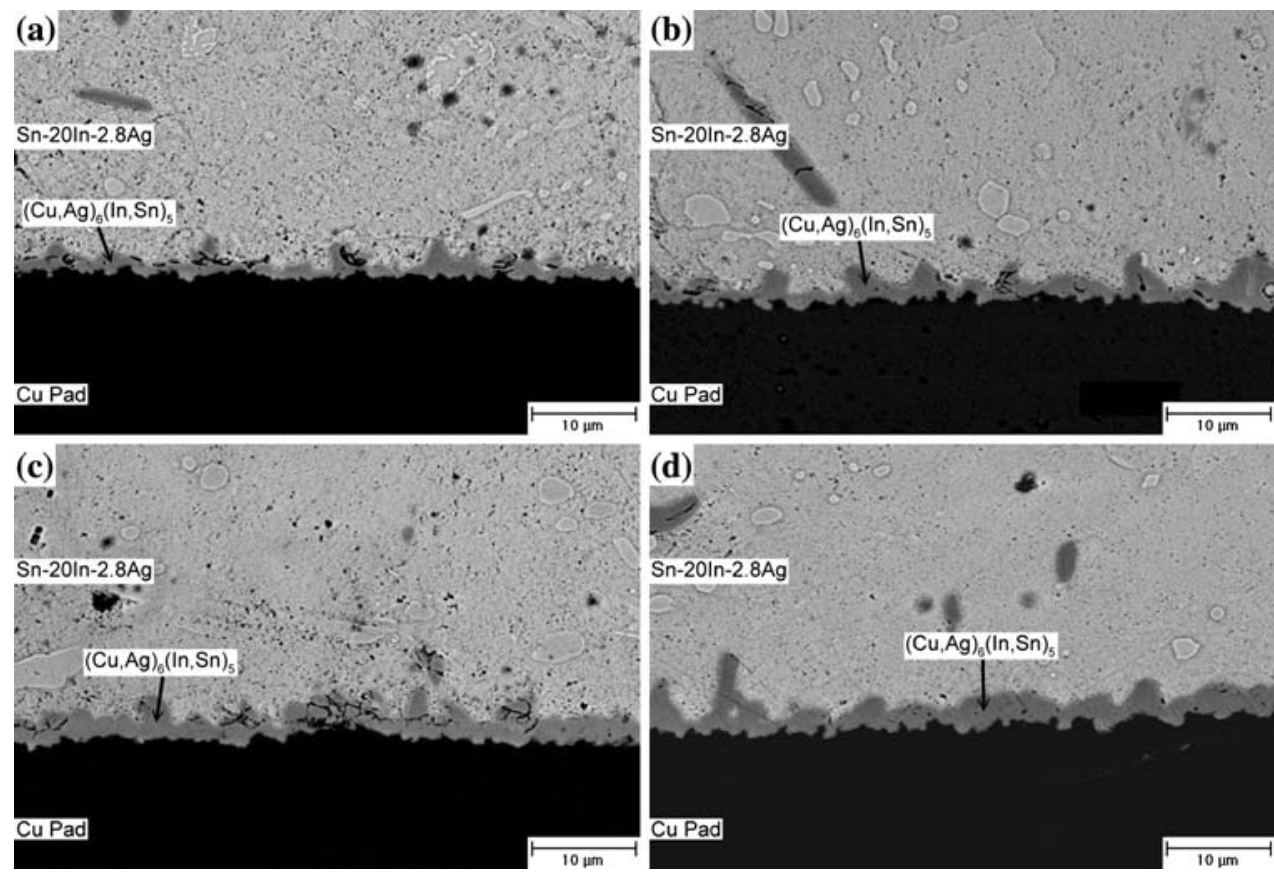

Fig. 5 Morphology of Sn-20In-2.8Ag solder balls and immersion $\mathrm{Ag}$ surface finish of $\mathrm{Cu}$ pads after aging at $100{ }^{\circ} \mathrm{C}$ for various time periods: (a) $100 \mathrm{~h}$, (b) $500 \mathrm{~h}$, (c) $700 \mathrm{~h}$, and (d) $1000 \mathrm{~h}$
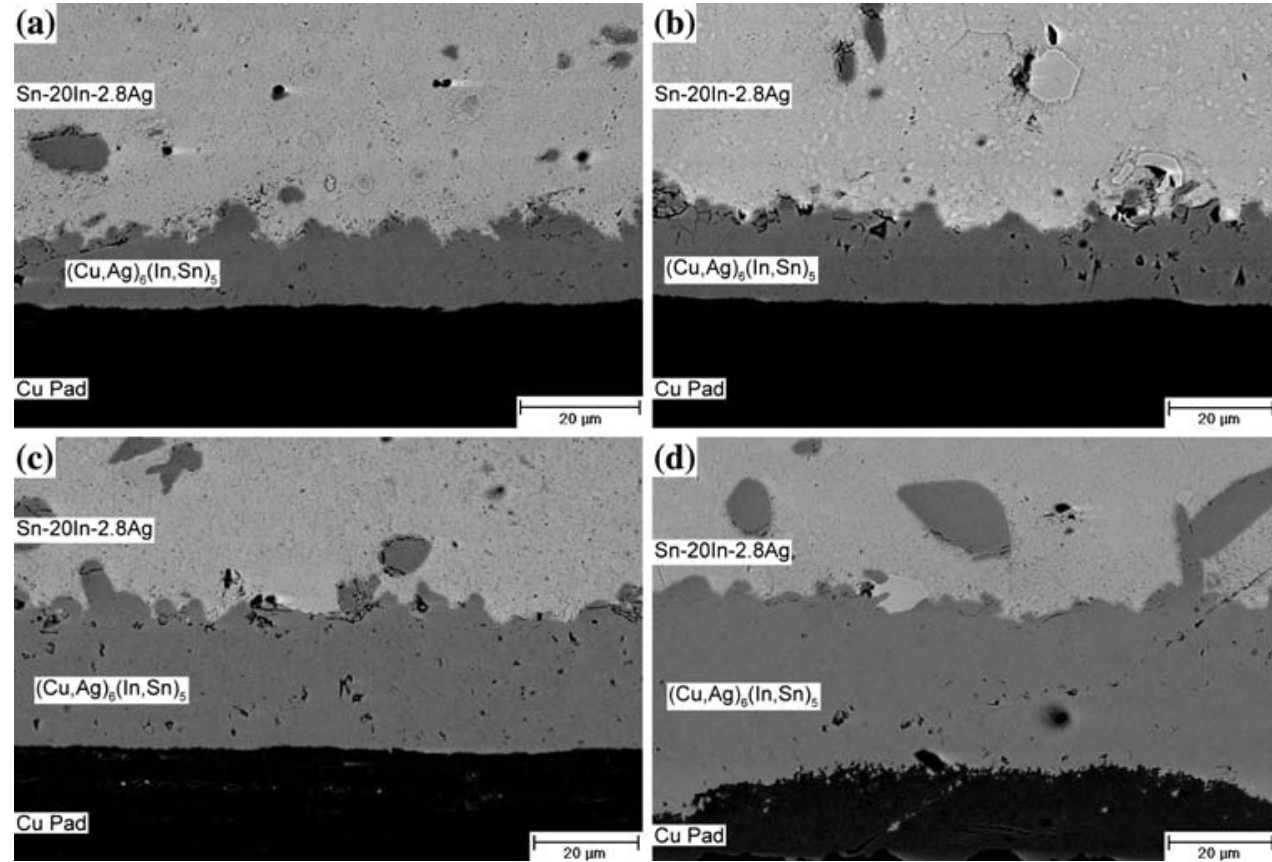

Fig. 6 Morphology of Sn-20In-2.8Ag solder balls and immersion $\mathrm{Ag}$ surface finish of $\mathrm{Cu}$ pads after aging at $150{ }^{\circ} \mathrm{C}$ for various times: (a) $100 \mathrm{~h}$, (b) $500 \mathrm{~h}$, (c) $700 \mathrm{~h}$, and (d) $1000 \mathrm{~h}$ 


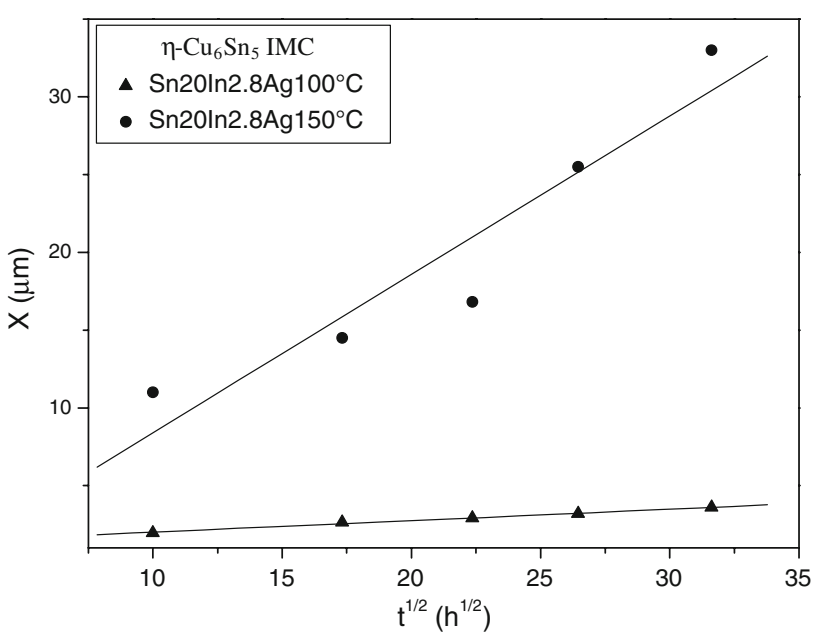

Fig. 7 Growth thickness $(X)$ of the intermetallic compound $\eta$-IMC during the aging of the Sn-20In-2.8Ag with immersion $\mathrm{Ag}$ surface finish at 100 and $150{ }^{\circ} \mathrm{C}$ versus the square root of time $\left(t^{1 / 2}\right)$

an $\varepsilon-\mathrm{Cu}_{3} \mathrm{Sn}$ intermetallic phase has often been reported to form between the $\eta-\mathrm{Cu}_{6} \mathrm{Sn}_{5}$ intermetallic layer and the $\mathrm{Cu}$ pad. Chih and Chuang found that during the aging process at $150{ }^{\circ} \mathrm{C}$ for an immersion $\mathrm{Ag}$ surface finished $\mathrm{Sn}-3.5 \mathrm{Ag}$ solder BGA package (Ref 14), an $\varepsilon-\mathrm{Cu}_{3} \mathrm{Sn}$ intermetallic layer appeared after the formation of $\eta-\mathrm{Cu}_{6} \mathrm{Sn}_{5}$ intermetallics. In addition, many Kirkendall voids were observed in the interior of the $\varepsilon-\mathrm{Cu}_{3} \mathrm{Sn}$ layer. The appearance of $\varepsilon-\mathrm{Cu}_{3} \mathrm{Sn}$ intermetallic compounds accompanying Kirkendall voids has also been reported in $\mathrm{Sn}-3.5 \mathrm{Ag}-0.5 \mathrm{Cu}$ solder joints with $\mathrm{Ag} / \mathrm{Cu}$ pads (Ref 15). The inhibition of the $\varepsilon-\mathrm{Cu}_{3} \mathrm{Sn}$ intermetallic phase seems to be a beneficial effect of the addition of indium on the immersion $\mathrm{Ag}$ surface finished Sn-20In-2.8Ag solder package.

The thickness $(X)$ of the $\eta-\left(\mathrm{Cu}_{0.98} \mathrm{Ag}_{0.02}\right)_{6}\left(\mathrm{Sn}_{0.59} \mathrm{In}_{0.41}\right)_{5}$ intermetallic compounds formed during the aging of Sn-20In$2.8 \mathrm{Ag}$ solder BGA packages with $\mathrm{Ag} / \mathrm{Cu}$ pads at 100 and $150{ }^{\circ} \mathrm{C}$ is plotted versus the square root of reaction time $\left(t^{1 / 2}\right)$ in Fig. 7. The curves exhibit a linear relation, which indicates that the growth of $\eta-\left(\mathrm{Cu}_{0.98} \mathrm{Ag}_{0.02}\right)_{6}\left(\mathrm{Sn}_{0.59} \mathrm{In}_{0.41}\right)_{5}$ intermetallics is diffusion-controlled. Ball shear strengths of the immersion $\mathrm{Ag}$ surface finished Sn-20In-2.8Ag solder BGA packages after aging at 100 and $150{ }^{\circ} \mathrm{C}$ are shown in Fig. 8. For comparison, the results of ball shear tests performed on Sn-20In-2.8Ag BGA packages with ENIG-surface finish $(\mathrm{Au} / \mathrm{Ni} / \mathrm{Cu}$ pads) in our prior study (Ref 9) are also given in Fig. 8. It is evident that the bonding strength of the as-reflowed Sn-20In-2.8Ag solder joints $(4.4 \mathrm{~N})$ with $\mathrm{Ag} / \mathrm{Cu}$ pads is lower than that of the ENIGsurface finished packages $(5.0 \mathrm{~N})$. After aging at 100 and $150{ }^{\circ} \mathrm{C}$ for $1000 \mathrm{~h}$, the bonding strengths of Sn-20In-2.8Ag solder joints with $\mathrm{Au} / \mathrm{Ni} / \mathrm{Cu}$ pads decline to $4.8 \mathrm{~N}$ and $3.7 \mathrm{~N}$, respectively. However, the ball shear strength of Sn-20In-2.8Ag solder joints after aging at $100{ }^{\circ} \mathrm{C}$ for $100 \mathrm{~h}$ climbs to $5.18 \mathrm{~N}$ and remains almost constant with the increase of the aging time. Aging at $150{ }^{\circ} \mathrm{C}$ for $100 \mathrm{~h}$ also causes an increase of the ball shear strength to $5.14 \mathrm{~N}$, while it declines slightly to $4.8 \mathrm{~N}$ for a longer aging time. Figure 9 shows the typical fractography of reflowed Sn-20In-2.8Ag solder joints in BGA packages after ball shear tests, which have mostly ruptured along the interface between $\left(\mathrm{Cu}_{0.98} \mathrm{Ag}_{0.02}\right)_{6}\left(\mathrm{Sn}_{0.59} \mathrm{In}_{0.41}\right)_{5}$ intermetallics and the solder pad. With further aging, more ductile fractured dimples throughout the matrix can be observed in the fractography, as

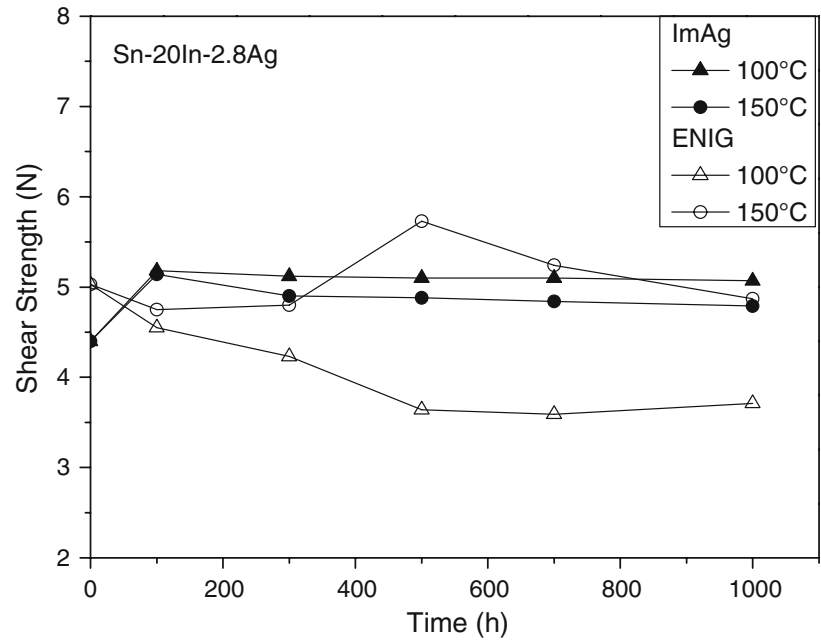

Fig. 8 The ball shear strengths of the Sn-20In-2.8Ag solder BGA packages with immersion $\mathrm{Ag}$ surface finish (ImAg) under various aging conditions. For comparison, the results of the ENIG-surface finished Sn-20In-2.8Ag packages measured in the prior study (Ref 9) are given in this figure

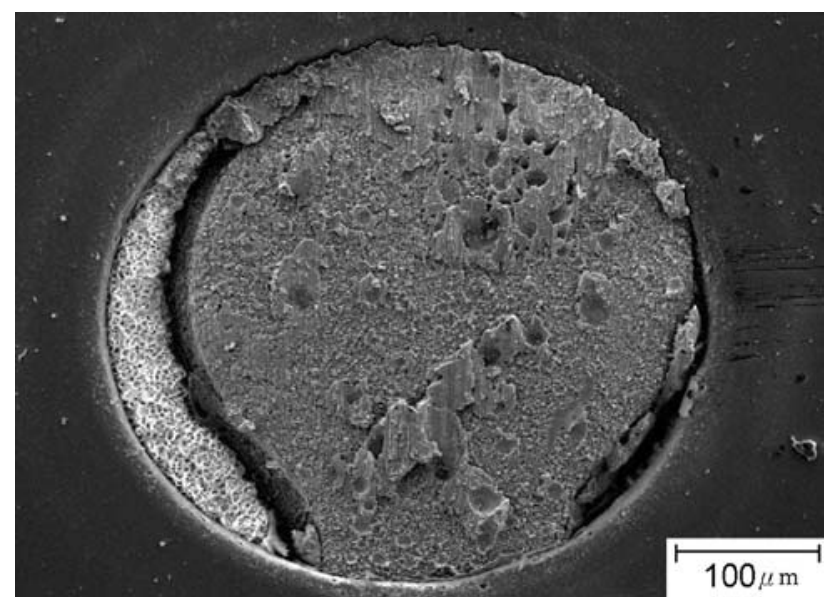

Fig. 9 Fractography of the as-reflowed Sn-20In-2.8Ag solder joints in BGA packages with immersion Ag surface finish after ball shear test

shown in Fig. 10. The results imply that the appearance of interfacial intermetallic compounds during aging processes at 100 and $150{ }^{\circ} \mathrm{C}$ leads to a more satisfactory reaction between $\mathrm{Sn}-20 \mathrm{In}-2.8 \mathrm{Ag}$ solder and the $\mathrm{Cu}$ pad, which transfers the fracture path from solder/pad interfaces to solder matrix.

\section{Conclusions}

After the reflow of Sn-20In-2.8Ag solder joints on immersion $\mathrm{Ag}$ surface finished $\mathrm{Cu}$ pads in ball grid array (BGA) packages, the Ag thin film has dissolved completely and caused the formation of $\eta-\left(\mathrm{Cu}_{0.98} \mathrm{Ag}_{0.02}\right)_{6}\left(\mathrm{Sn}_{0.59} \mathrm{In}_{0.41}\right)_{5}$ at the interfaces between the solder balls and the $\mathrm{Cu}$ pads. A great number of island-like precipitates with a composition of $\left(\mathrm{Ag}_{0.94}\right.$ $\left.\mathrm{Cu}_{0.06}\right)_{2} \mathrm{In}$ are embedded in the $\mathrm{Sn}$-rich matrix. After prolonged 

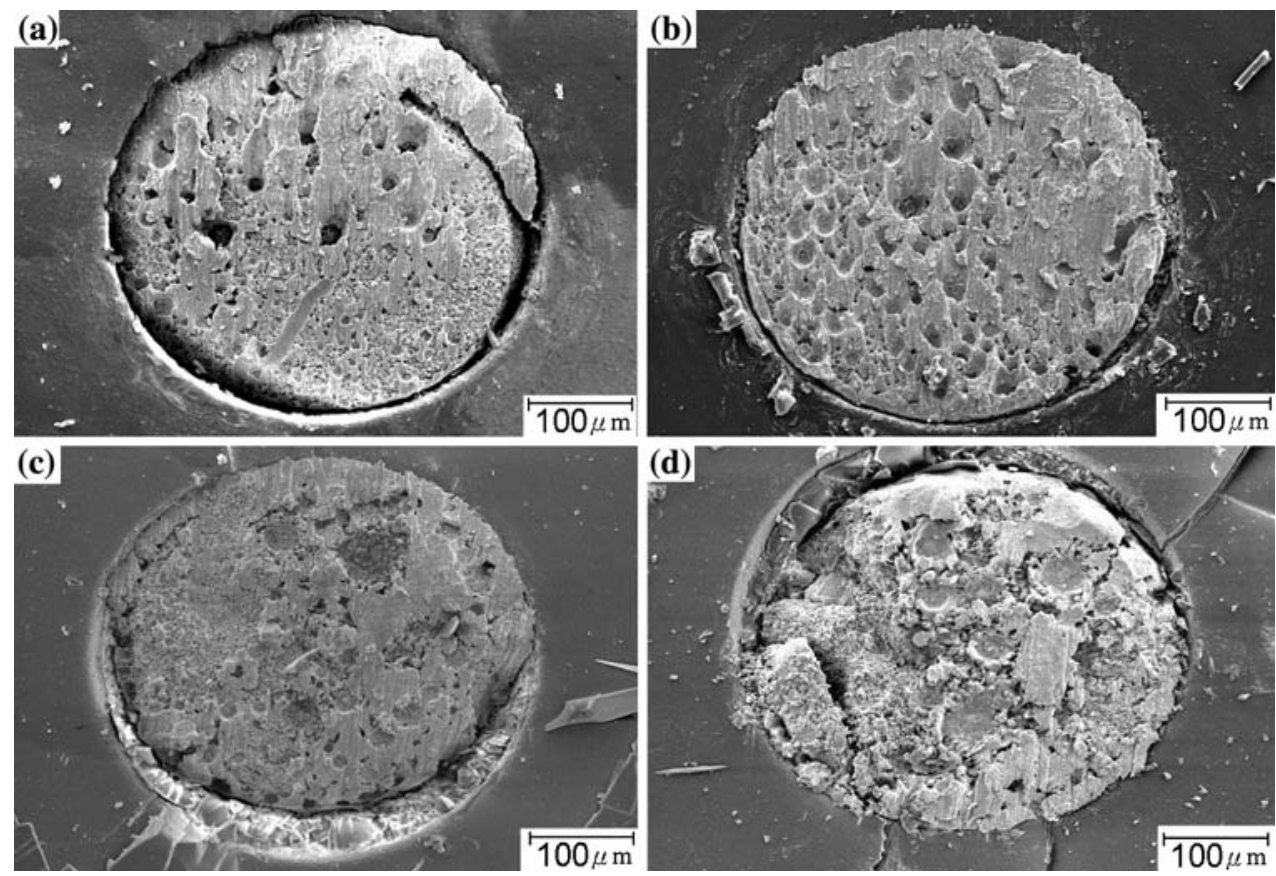

Fig. 10 Fractography of the aged Sn-20In-2.8Ag solder joints in BGA packages with immersion Ag surface finish after ball shear tests: (a) $100{ }^{\circ} \mathrm{C}, 100 \mathrm{~h}$, (b) $100{ }^{\circ} \mathrm{C}, 1000 \mathrm{~h}$, (c) $150{ }^{\circ} \mathrm{C}, 100 \mathrm{~h}$, and (d) $150{ }^{\circ} \mathrm{C}, 1000 \mathrm{~h}$

aging at $150{ }^{\circ} \mathrm{C}$, a $\eta-\left(\mathrm{Cu}_{0.98} \mathrm{Ag}_{0.02}\right)_{6}\left(\mathrm{Sn}_{0.59} \mathrm{In}_{0.41}\right)_{5}$ intermetallic layer appears at the interface and grows rapidly. The occurrence of $\varepsilon-\mathrm{Cu}_{3} \mathrm{Sn}$ phase has been inhibited on the immersion $\mathrm{Ag}$ surface finished by the addition of indium to $\mathrm{Sn}-20 \mathrm{In}-2.8 \mathrm{Ag}$ solder. The growth of $\eta-\left(\mathrm{Cu}_{0.98} \mathrm{Ag}_{0.02}\right)_{6}\left(\mathrm{Sn}_{0.59} \mathrm{In}_{0.41}\right)_{5}$ follows a linear relation, indicating that the reaction is diffusioncontrolled. The ball shear strength of the immersion Ag surface finished Sn-20In-2.8Ag solder BGA packages after aging at 100 and $150{ }^{\circ} \mathrm{C}$ increases from $4.4 \mathrm{~N}$ (reflowed state) to $5.18 \mathrm{~N}$ and $5.14 \mathrm{~N}$, respectively. The increase of bonding strength for solder joints in this case is attributed to the more satisfactory interfacial reaction between the Sn-20In-2.8Ag solder and the $\mathrm{Cu}$ pad during the aging process.

\section{Acknowledgments}

The authors sincerely acknowledge the financial support for this research from National Taiwan University under Grant No. 96R0210 and the National Science Council, Taiwan, under Grant No. NSC. 93-2216-E002-024.

\section{References}

1. A.M. Minor and J.W. Morris, Inhibiting Growth of the $\mathrm{Au}_{0.5} \mathrm{Ni}_{0.5} \mathrm{Sn}_{4}$ Intermetallic Layer in $\mathrm{Pb}-\mathrm{Sn}$ Solder Joints Reflowed on $\mathrm{Au} / \mathrm{Ni}$ Metallization, J. Electron. Mater., 2000, 29(10), p 1170-1174

2. Z. Mei, M. Kaufmann, A. Eslambolchi, and P. Johnson, Brittle Interfacial Fracture of PBGA Packages Soldered on Electroless Nickel/ Immersion Gold, IEEE Electron. Compon. and Technol. Conf., 1998, p $952-961$

3. J.H. Lau, C.P. Wong, N.C. Lee, and S.W. Ricky Lee, Electronics Manufacturing with Lead-free, Halogen-free Conductive-Adhesive Materials, McGraw-Hill Handbooks, 2003
4. J. Glazer, Metallurgy of Low Temperature $\mathrm{Pb}$-free Solders for Electronics Assembly, Int. Mater. Rev., 1995, 40(2), p 65-93

5. Z. Mei and J.W. Morris, Characterization of Eutectic Sn-Bi Solder Joints, J. Electron. Mater., 1992, 21(6), p 599-607

6. K. Shimizn, T. NaKanishi, K. Karasawa, K. Hashimoto, and K. Niwa, Solder Joint Reliability of Indium-Alloy Interconnection, J. Electron. Mater., 1995, 24(1), p 39-45

7. T.H. Chuang, K.W. Huang, and W.H. Lin, Mechanisms for the Intermetallic Formation During the Sn-20In-2.8Ag/Ni Soldering Reactions, J. Electron. Mater, 2004, 33(4), p 374-382

8. M.J. Chiang and T.H. Chuang, Interfacial Reaction Between Liquid Sn-20In-2.8Ag Solder and Ag Substrate, Z. Metallkd., 2002, 93(12), p 1194-1198

9. H.M. Wu, F.C. Wu, and T.H. Chuang, Intermetallic Reactions in a Sn-20In-2.8Ag Solder Ball-Grid-Array Package with $\mathrm{Au} / \mathrm{Ni} / \mathrm{Cu}$ Pads, J. Electron. Mater, 2005, 34(11), p 1385-1390

10. T.L. Su, L.C. Tsao, S.Y. Chang, and T.H. Chuang, Interfacial Reactions of Liquid Sn and Sn-3.5Ag Solders with Ag Thick Films, J. Mater. Eng. Perform., 2002, 11(5), p 481-486

11. D.W. Henderson, T. Gosselin, A. Sarkhel, S.K. Kang, W.K. Choi, D.Y. Shih, C. Goldsmith, and K.J. Puttlitz, $\mathrm{Ag}_{3} \mathrm{Sn}$ Plate Formation in the Solidification of Near Ternary Eutectic Sn-Ag-Cu Alloys, J. Mater. Res., 2002, 17(11), p 2775-2778

12. M.D. Cheng, S.Y. Chang, S.F. Yen, and T.H. Chuang, Intermetallic Compounds Formed During the Reflow and Aging of Sn-3.8Ag- $0.7 \mathrm{Cu}$ and Sn-20In-2Ag-0.5Cu Solder Ball Grid Array Packages, J. Electron. Mater, 2004, 33(3), p 171-180

13. T.Y. Lee, W.J. Choi, K.N. Tu, J.W. Jang, S.M. Kuo, J.K. Lin, D.R. Frear, K. Zeng, and J.K. Kivilathi, Morphology, Kinetics, and Thermodynamics of Solid-State Aging of Eutectic $\mathrm{SnPb}$ and $\mathrm{Pb}$-free Solders $(\mathrm{Sn}-3.5 \mathrm{Ag}, \mathrm{Sn}-3.8 \mathrm{Ag}-0.7 \mathrm{Cu}$ and $\mathrm{Sn}-0.7 \mathrm{Cu})$ on $\mathrm{Cu}, J$. Mater. Res., 2002, 17(2), p 291-301

14. C.C. Chi and T.H. Chuang, Intermetallic Reactions in Sn-3.5Ag Solder Ball Grid Array Packages with $\mathrm{Ag} / \mathrm{Cu}$ and $\mathrm{Au} / \mathrm{Ni} / \mathrm{Cu}$ Pads, J. Electron. Mater., 2006, 35(3), p 471-478

15. T.H. Chuang, S.F. Yen, and H.M. Wu, Intermetallic Formation in $\mathrm{Sn} 3 \mathrm{Ag} 0.5 \mathrm{Cu}$ and $\mathrm{Sn} 3 \mathrm{Ag} 0.5 \mathrm{Cu} 0.06 \mathrm{Ni0} .01 \mathrm{Ge}$ Solder BGA Packages with Immersion Ag Surface Finish, J. Electron. Mater, 2006, 35(2), p 310-318 